\title{
KEMAMPUAN REPRESENTASI MATEMATIS DAN SELF CONFIDENCE SISWA SMP MELALUI PENERAPAN MODEL PROBLEM BASED LEARNING (PBL)
}

\author{
Yuni Herdiana ${ }^{1}$ Marwan $^{1}$, Cut Morina Zubainur ${ }^{1}$ \\ ${ }^{1}$ Universitas Syiah Kuala, Jl.Tgk Chik Pante Kulu, Banda Aceh 23111, Indonesia \\ Email: yuni.herdiana91@gmail.com \\ Email: marwan.math@unsyiah.ac.id \\ Email: cutmorina@gmail.com
}

\begin{abstract}
Abstrak
Penelitian ini bertujuan untuk mengetahui perkembangan kemampuan representasi matematis dan Self Confindece siswa SMP melalui penerapan model Problem Based Learning (PBL). Jenis penelitian ini adalah penelitian kualitatif. Subjek yang digunakan dalam penelitian ini adalah dua orang siswa kelas VII. Pengambilan siswa berdasarkan hasil tes dan konsultasi dengan guru. Pengumpulan data dilakukan menggunakan tes dan wawancara semi terstruktur. Instrumen yang digunakan untuk memperoleh data kemampuan representasi matematis selama proses pembelajaran dengan menggunakan model pembelajaran PBL berupa hasil tes individu setiap pertemuan, sedangkan instrumen yang digunakan untuk memperoleh data Self Confidece siswa berupa angket. Hasil penelitian menunjukkan bahwa pembelajaran dengan model PBL dapat membantu menumbuhkan perkembangan kemampuan representasi matematis siswa terlihat dari hasil tes individu setiap pertemuan dan hasil wawancara semi terstruktur siswa. Meskipun siswa belum dapat memenuhi semua indikator yang diukur, namun terlihat sebahagian besar siswa telah dapat memenuhi sebahagian besar indikator representasi matematis yaitu (1) menyajikan data atau informasi dari suatu masalah ke representasi gambar, diagram, grafik atau tabel, (2) menyelesaikan masalah yang melibatkan ekspresi matematis. Hanya satu indikator kemampuan representasi matematis yang tidak terpenuhi yaitu menuliskan langkah-langkah penyelesaian masalah matematika. Kemampuan Self Confindece siswa mengalami perkembangan secara klasikal dan memiliki dampak positif terhadap kemampuan representasi matematis siswa terhadap proses pembelajaran PBL sesuai dengan indikator Self Confindece. Penelitian ini memberikan gambaran tentang pentingnya melatih siswa menjawab soal nonroutin melalui pembelajaran. Tantangan bagi guru untuk membiasakan siswa merepresentasi dan melakukan langkah-langkah penyelesaian masalah secara sistematis serta memiliki kepercayaan diri dalam menjawab soal. Pembelajaran yang dilaksanakan guru berpengaruh terhadap terbentuknya kebiasaan siswa.
\end{abstract}

Katakunci : kemampuan representasi matematis, self confindece,model PBL

\begin{abstract}
This research is to know the development of mathematical representation abilities and self-confidence of junior high school students through the application of the Problem Based Learning (PBL) model.This type of research is qualitative research. The subjects used in this research isthe students of Junior High School at class VII. The students are taking by consultation with the teacher. Data collection was performed using semi-structured tests and interviews.The instrument used to obtain mathematical representation ability data during the learning process by using the PBL learning model in the form of individual test results at each meeting, while the instrument used to obtain students' Self Confidence data in the form of a questionnaire.The results was showed that learn with the PBL model can help students to grow the development of students 'mathematical representation abilities seen from the results of individual tests at each meeting and the results of students' semistructured interviews. Although students have not been able to meet all the measured indicators, it appears that most students have been able to meet most of the mathematical representation indicators, namely (1) presenting
\end{abstract}


data or information from a problem to the representation of images, diagrams, graphs or tables, (2) solving problems that involves mathematical expressions. Only one indicator of mathematical representation ability that is not fulfilled is to write steps to solve mathematical problems. The ability of Self Confindece students have developed classically and has a positive impact on the ability of students' mathematical representation of the PBL learning process in accordance with the Self Confindece indicator. This study provides an overview of the importance of training students to answer non-routin problems through learning. The challenge for the teacher is to get the students to represent and take steps to solve problems systematically and have confidence in answering questions. Learning conducted by the teacher influences the formation of student habits.

Keywords : The Ability of Representation, Self-Confidence, Model Problem Based Learning

\section{PENDAHULUAN}

Pembelajaran matematika yang dilaksanakan guru bertujuan untuk mencapai kemampuan yang dimiliki oleh siswa. Kemampuan yang harus dimiliki siswa dalam pembelajaran matematika yaitu kemampuan representasi matematis. Kemampuan representasi adalah kemampuan mengungkapkan ide-ide matematis sebagai model yang digunakan untuk menemukan solusi dari masalah yang dihadapinya sebagai hasil interpretasi pikirannya, sehingga siswa dapat menganalisis masalah dan merencanakan pemecahan masalah matematika yang di hadapi (Alhadad, 2010). Sementara itu, Panaoura (2011) mengungkapkan kemampuan representasi matematis adalah alat yang berguna untuk memahami konsep-konsep geometri dan menggunakan representasi untuk menyelesaikan tugas dan untuk menjelaskan kepada orang lain. Vergnaud (English, 2014) menyatakan representasi merupakan unsur yang penting dalam teori belajar mengajar matematika, tidak hanya kerena pemakaian sistem simbol juga penting dalam matematika dan kaya akan kalimat dan kata, beragam dan universal, tetapi juga untuk dua alasan penting yakni: (1) matematika mempunyai peranan penting dalam mengkonseptualisasi dunia nyata; (2) matematika turunan dari struktur hal-hal lain yang pokok.

Hasil TIMSS (Trends in International Mathematics and Science Study) pada tahun 2015 menunjukkan bahwa bahwa $81-91 \%$ siswa Indonesia menguasai soal-soal yang bersifat rutin, komputasi sederhana, serta mengukur pengetahuan akan fakta yang berkonteks (Rahmawati, 2016). Salah satu kunci keberhasilan dalam menyelesaikan masalah adalah merepresentasikan masalah secara tepat Schon (Mahmudi, 2010). Sejalan dengan itu Chamberlin (2008) juga mengungkapkan bahwa salah satu komponen pemecahan masalah adalah representasi, yakni merepresentasikan ide-ide matematis yang berkaitan dengan masalah secara ringkas dan sederhana sehingga mudah untuk diolah dan dioperasikan serta dicari solusinya. Siswa yang terbiasa mengerjakan soal-soal rutin dan meniru cara guru dalam menyelesaikan masalah akan mengalami kesulitan ketika mendapat soal-soal tidak rutin. Indikator representasi matematis yang digunakan dalam penelitian ini yaitu: (1) Menyajikan data atau informasi dari suatu masalah ke representasi gambar, diagram, grafik atau tabel, (2) Menyelesaikan masalah yang melibatkan ekspresi matematis, dan (3) Menuliskan langkah-langkah penyelesaian masalah matematika (Mudzakir, 2006).

Selain kemampuan representasi dalam pemecahan masalah, terdapat aspek afektif yang harus diperhatikan siswa dalam pembelajaran matematika yaitu Self Confindece. Menurut Hendriana (2012) Self Confidence adalah kepercayaan terhadap diri sendiri, untuk memperkuat tekad dalam menyelesaikan segala tugasnya. Hasil TIMSS (Trends in International Mathematics and Science Study) pada tahun 2015 menunjukkan hanya 23\% siswa Indonesia yang percaya diri terhadap kemampuan matematika yang dimilikinya, hal ini relatif rendah dibandingkan negara-negara lainnya.

Pengembangan self-confidence di sekolah masih belum nampak. Hal ini di tunjukkan dari penelitian Rohayati (2011) yaitu masih banyak siswa Indonesia kurang memiliki rasa percaya diri. 
Siswa akan merasa gugup dan tegang jika dihadapkan pada masalah. Hasil penelitian Mullis (2012) menunjukkan bahwa tingkat self confidence siswa Indonesia masih rendah. Siswa tidak berani untuk mempresentasikan hasil pekerjaannya di depan kelas karena merasa tidak percaya diri.

Pengamatan peneliti terhadap 27 siswa kelas VII menunjukkan bahwa kemampuan representasi matematis siswa masih rendah dan belum memenuhi indikator yang diukur. Hal ini ditunjukkan dari pencapaian hasil belajar siswa yang belum tuntas. Rendahnya kemampuan representasi matematis siswa memerlukan upaya memperbaikinya. Siswa perlu dilatih menyelesaikan permasalahan non rutin dan difasilitasi untuk membuat gambar/diagram, menulis persamaan, atau mengkreasi bentuk representasi lain yang lebih tepat.

Upaya yang dilakukan untuk melatih siswa menyelesaikan permasalahan non rutin dengan konteks matematika dalam kehidupan sehari-hari. Pembelajaran tersebut dapat dilaksanakan melalui model Problem Based Learning (PBL). PBL adalah pembelajaran atau pengajaran yang memberi siswa pengalaman masalah dan menerima instruksi apapun sebelumnya (Merrit, 2017). Selanjutnya Hmelo (2006), menyatakan bahwa PBL adalah suatu metode pembelajaran yang membuat siswa lebih aktif berdasarkan masalah yang tidak terstruktur sebagai rangsangan untuk belajar. Problem based learning $(P B L)$ dapat menciptakan kondisi bagi peserta didik untuk mengembangkan dan mempertahankan keterampilan belajar mandiri sehingga pembelajaran lebih bermakna, ditandai dengan mengolah materi pelajaran secara kritis (Malan dan Ndlovu, 2014). Pelaksanaan model pembelajaran yang menerapkan $P B L$, peserta didik akan bekerja dalam tim untuk memecahkan masalah dunia nyata (real world) sehingga bekerja dalam tim dapat meningkatkan interaksi antar sesama peserta didik serta menambah keterampilan peserta didik dalam menyelesaikan permasalahan kehidupan nyata (Majid, 2014).

Penelitian yang dilakukan oleh Sulis Widarti (2014) bahwa penerapan model problem based learning dapat meningkatkan kemampuan representasi matematis siswa. Oleh karena itu, tujuan dalam penelitian ini, yaitu mengidentifikasi perkembangan kemampuan representasi matematis dan Self Confindece siswa melalui model PBL.

\section{METODE PENELITIAN}

Pendekatan yang digunakan dalam penelitian ini adalah pendekatan kualitatif. Siswa yang dilibatkan dalam penelitian ini adalah siswa sekolah menengah yang berjumlah 27 orang. Dari 27 siswa dipilih enam siswa yaitu dua siswa dengan kriteria tinggi, dua siswa dengan kriteria sedang, dan dua siswa dengan kriteria rendah untuk diwawancarai. Pada makalah ini hanya menguraikan kemampuan representasi matematis dan Self Confindece tiga siswa dengan kriteria tinggi, sedang, rendah. Dari tiga kriteria siswa tersebut hanya difokuskan 2 orang siswa yaitu kriteria sedang (siswa 1) dan kriteria rendah (siswa 2), sedangkan kriteria tinggi sudah mencapai ketuntasan. Pembelajaran dalam penelitian ini di laksanakan sebanyak enam kali pertemuan.

Pemilihan siswa didasarkan pada hasil tes awal dan wawancara dengan guru matematika yang mengajar di kelas mengenai kemampuan representasi matematis bahwa siswa tersebut dapat memberikan data yang cukup dalam penelitian. Instrumen yang digunakan meliputi tes kemampuan representasi matematis, angket Self Confindece, dan wawancara semiterstruktur. Wawancara semi terstruktur dilakukan untuk memperkuat hasil tes siswa dan peneliti langsung mewawancarai dengan siswanya berdasarkan hasil tes yang diperoleh. Tes digunakan untuk memperoleh data tentang perkembangan kemampuan representasi matematis bangun datar segi empat selama proses belajar dengan menggunakan model PBL. Tes yang diberikan berupa tes bentuk uraian dan penyusunannya 
disesuaikan dengan indikator kemampuan representasi matematis yang diukur yaitu (1) menyajikan data atau informasi dari suatu masalah ke representasi gambar, diagram, grafik atau tabel, (2) menyelesaikan masalah yang melibatkan ekspresi matematis, dan (3) kemampuan representasi matematis yang tidak terpenuhi yaitu menuliskan langkah-langkah penyelesaian masalah matematika. Angket merupakan daftar pernyataan yang telah disusun sedemikian rupa sehingga diharapkan responden memberikan jawaban langsung pada angket tersebut. Angket Self Confindece diberikan pada siswa setelah proses pembelajaran berlangsung. Angket divalidasi oleh tiga orang validator yaitu dua orang dosen Magister pendidikan Matematika, satu orang guru mata pelajaran Matematika dan satu orang teman sejawat. Hasil validasi dari angket sudah bisa digunakan dengan sedikit revisi. Proses analisis data meliputi reduksi data, penyajian data, dan penarikan kesimpulan.

\section{HASIL PENELITIAN DAN PEMBAHASAN}

Data perkembangan kemampuan representasi matematis dengan materi bangun datar segi empat dapat dilihat dari dua siswa, yaitu kriteria sedang (siswa 1) dan kriteria rendah (siswa 2). Kemampuan representasi matematis siswa diperoleh berdasarkan hasil tes individu setiap pertemuan berdasarkan indikator kemampuan representasi matematis yaitu (1) menyajikan data atau informasi dari suatu masalah ke representasi gambar, diagram, grafik atau tabel, (2) menyelesaikan masalah yang melibatkan ekspresi matematis, dan (3) menuliskan langkah-langkah penyelesaian masalah matematika. Model pembelajaran yang digunakan adalah model PBL.

\section{Kemampuan Menyajikan Data atau Informasi dari Suatu Masalah ke Representasi Gambar, Diagram, Grafik atau Tabel}

Pada pertemuan pertama sampai keenam diukur indikator menyajikan data atau informasi dari suatu masalah ke representasi gambar, diagram, grafik atau tabel. Indikator ini diukur melalui soal tentang bangun datar segi empat. Salah satu indikator yang dipenuhi oleh semua siswa setiap pertemuan yaitu indikator pertama, namun ada siswa yang tidak memenuhi indikator pertama pada pertemuan pertama. Hal ini ditunjukkan oleh jawaban siswa terhadap butir tes berikut.

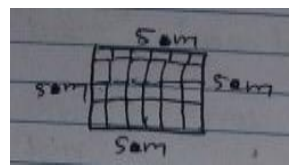

Gambar 1. Jawaban siswa 1 no 1

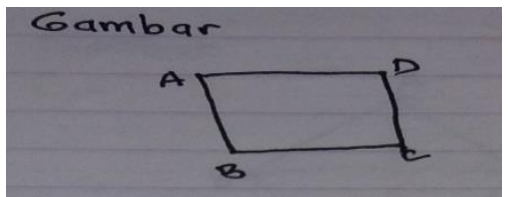

Gambar 2. jawaban siswa 2 soal no 1

Berdasarkan hasil jawaban siswa 1 sudah benar menggambar bangun persegi sesuai perintah soal, sedangkan siswa 2 belum benar menggambarkan bangun persegi melainkan mengambar bangun jajargenjang.

Kemampuan siswa 2 dalam menyajikan data atau informasi dari suatu masalah ke representasi gambar, diagram, grafik atau tabel belum tepat dan ditunjukkan dari jawaban siswa 2 ketika dilakukan wawancara semi terstruktur. Hal ini seperti ditunjukkan petikan wawancara berikut. 
P : Coba kamu perhatikan soalnya, apa yang ditanya dari soal 1a?

S : Gambarkan buk.

P : Apa kamu bisa gambarkan?

S : Bisa ibu (mengambarkan persegi)

$\mathrm{P} \quad$ : Apa nama bangun yang kamu gambarkan dan berapa sisinya?

S : : Persegi dan sisinya 5.

$\mathrm{P} \quad$ : Kenapa gambar perseginya miring?

S : Karena tidak ada rol buk, makanya gambarnya kek gitu.

$\mathrm{P} \quad$ : Jika ada rol, apa kamu ingin mengambarkan kembali?

S : Boleh buk, (sambil mengambar, tetapi juga tetap mirip gambar jajargenjang)

Berdasarkan hasil jawaban dan wawancara dapat di simpulkan bahwa, siswa 1 sudah memenuhi indikator pertama Sedangkan siswa 2 belum memenuhi indikator pertama untuk pertemuan pertama. Pertemuan kedua sampai keenam sebagian besar siswa memenuhi indikator pertama dengan baik dan mengalami perkembangan yaitu menyajikan data atau informasi dari suatu masalah ke representasi gambar, diagram, grafik atau tabel.

\section{Kemampuan Menyelesaiakan Masalah yang Melibatkan Ekpresi Matematis}

Pada pertemuan pertama untuk indikator kedua yaitu kemampuan menyelesaikan masalah yang melibatkan ekspresi matematis, siswa 1 sudah mampu menyelesaikan permasalah $\mathrm{b}$ dan $\mathrm{c}$ dengan tepat dan perhitungan serta langkah-langkah penyelesaian juga benar. Namun, hasil satuan pengukuran salah dan yang benar yaitu $25 \mathrm{~m}^{2}$ bukan $25 \mathrm{~m}$ untuk no c. Berikut ini hasil jawaban siswa 1:

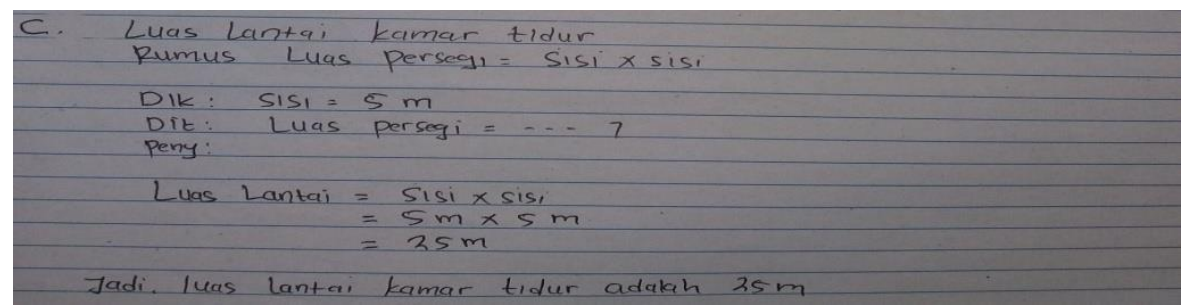

Gambar 3. Hasil jawaban siswa 1

Siswa 2 untuk pertemuan pertama soal no b sudah tepat untuk indikator kedua, namun tidak lengkap membuat langkah penyelesaian. Sedangkan untuk no d siswa 2 langsung menulis banyak ubin $=20 \times 25=500$. Namun, hasil perhitungan salah, tidak menulis satuan pengukuran meter, serta rumusnya juga salah. Berikut Hasil jawaban siswa 2 untuk soal no d.

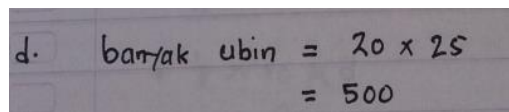

Gambar 4. Hasil Jawaban siswa 2 no d

Berdasarkan hasil jawaban dapat di simpulkan bahwa, siswa 1 sudah memenuhi indikator kedua Sedangkan siswa 2 belum memenuhi indikator kedua untuk pertemuan pertama. 
Pada pertemuan kedua untuk indikator kedua yaitu kemampuan menyelesaikan masalah yang melibatkan ekspresi matematis. Siswa 1 mampu menyelesaikan permasalah no b dengan tepat dan perhitungan serta langkah-langkah penyelesaian juga benar sesuai perintah soal sedangkan no c mampu menyelesaikan masalah yang melibatkan ekspresi matematis dengan benar dalam menulis diketahui, ditanya pada luas tanah, namun untuk luas $1 / 3$ kebun dan sisa tanah dibuat rumah salah. Berikut Hasil jawaban siswa 2 untuk soal no c.

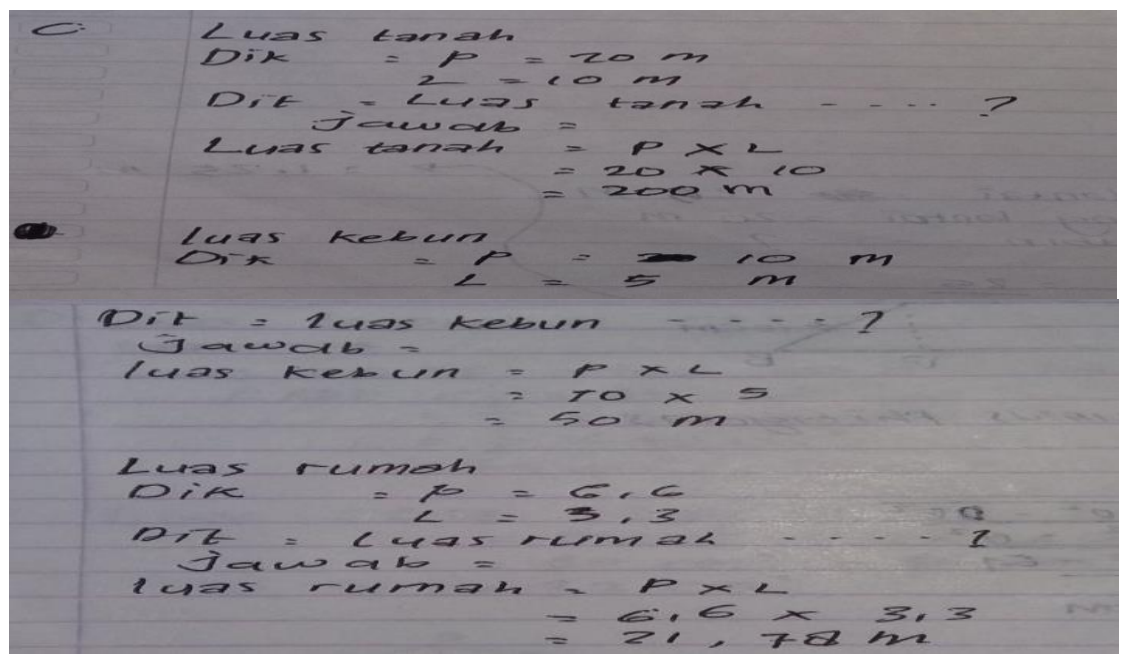

Gambar 5. Hasil Jawaban Siswa 1 no c

Siswa 2 mampu menyelesaikan permasalah no b dengan tepat dan perhitungan benar, namun tidak menulis diketahui dan ditanya. Siswa 2 untuk soal no c tidak menulis diketahui dan ditanya, namun langsung mencari luas tanah dengan menggunakan rumus yaitu p x $1=20 \times 10=200$. Pengerjaan perhitungan benar, namun satuan pengukuran salah yang benar yaitu $20 \mathrm{~m}^{2}$. Siswa IR juga tidak mengerjakan luas 1/3 kebun dan sisa tanah. Berikut Hasil jawaban siswa 2 untuk soal no c.

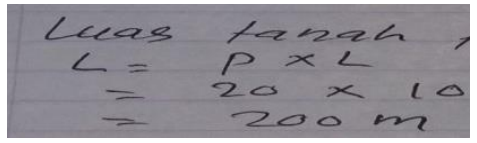

Gambar 6. Hasil jawaban siswa 2 no c

Berdasarkan penjelasan diatas secara keseluruhan pada pertemuan kedua dapat disimpulkan bahwa siswa 1 memenuhi indikator kedua sedangkan siswa 2 belum memenuhi indikator kedua untuk pertemuan kedua yaitu (2) menyelesaiakan masalah yang melibatkan ekpresi matematis.

Pada pertemuan ketiga untuk indikator kedua yaitu kemampuan menyelesaikan masalah yang melibatkan ekspresi matematis, siswa 1 untuk no b mampu menyelesaikan masalah yang melibatkan ekspresi matematis dengan benar dalam menulis diketahui, ditanya serta mengerjakan perhitungan dengan benar dan tepat sedangkan menyelesaikan permasalah no c sudah tepat dan perhitungan serta langkah-langkah penyelesaian juga benar sesuai perintah soal. Namun, hasil akhir untuk banyak stiker salah, karena rumusnya bukan dibagi tetapi dikalikan yaitu 24 × $2=48$. Berikut Hasil jawaban siswa 1 untuk soal no c. 


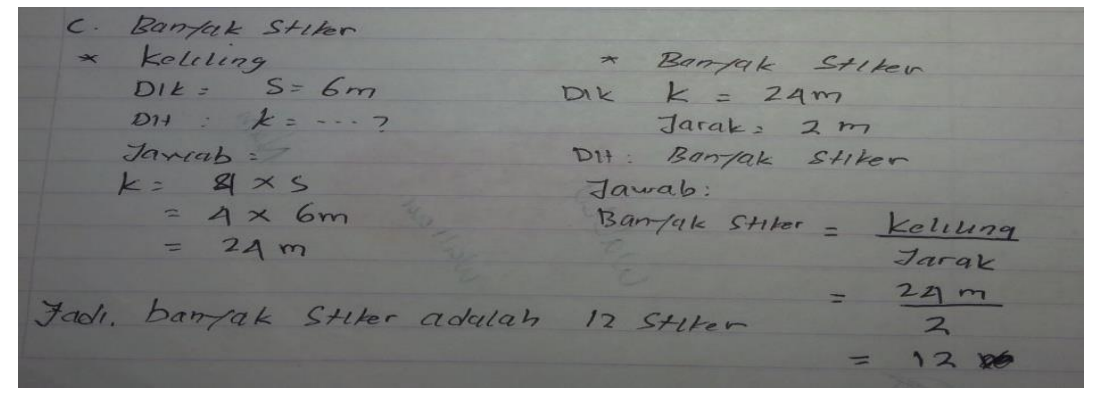

Gambar 6. Hasil Jawaban siswa 1 no c.

Siswa 2 belum mampu menyelesaikan permasalah no $\mathrm{b}$ dengan tepat dan perhitungan, rumus, serta langkah-langkah penyelesaian juga salah. Berikut Hasil jawaban siswa 2 untuk soal no b.

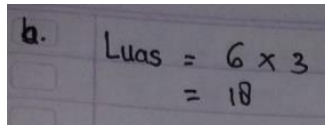

Gambar 7. Hasil jawaban siswa 2 no b.

Siswa 2 belum mampu menyelesaikan permasalah no c dengan tepat dan perhitungan, rumus, serta langkah-langkah penyelesaian juga salah. Berikut Hasil jawaban siswa 2 untuk soal no c.

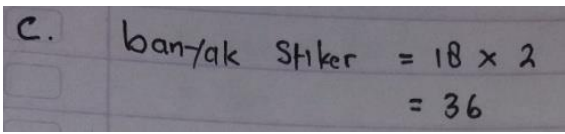

Gambar 8. Hasil Jawaban siswa 2 no c

Berdasarkan hasil jawaban siswa pada pertemuan ketiga dapat disimpulkan bahwa siswa 1 memenuhi indikator kedua walaupun ada belum tepat sedangkan siswa 2 belum memenuhi indikator kedua secara tepat yaitu (2) menyelesaiakan masalah yang melibatkan ekpresi matematis.

Pada pertemuan keempat untuk indikator kedua yaitu kemampuan menyelesaikan masalah yang melibatkan ekspresi matematis, Siswa 1 mampu menyelesaikan permasalah no b dan c dengan tepat dan perhitungan serta langkah-langkah penyelesaian juga benar sesuai perintah soal. Siswa 2 belum mampu menyelesaikan permasalah no $\mathrm{b}$ dengan tepat dan perhitungan serta langkah-langkah penyelesaian salah. Berikut Hasil jawaban siswa 2 untuk soal no b.

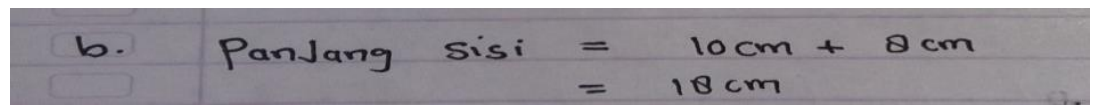

Gambar 9. Hasil Jawaban siswa 2 no b

Siswa 2 tidak menulis diketahui, ditanya, namun langsung mencari keliling yaitu $2 \times 18 \mathrm{~cm}=$ $36 \mathrm{~cm}$. Siswa 2 belum mampu menyelesaikan permasalah no c dengan tepat dan perhitungan serta langkah-langkah penyelesaian salah. Berikut Hasil jawaban siswa 2 untuk soal no c.

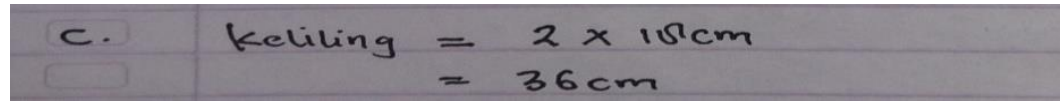

Gambar 10. Hasil Jawaban Siswa 2 no c 
Berdasarkan hasil jawaban siswa pada pertemuan keempat dapat disimpulkan bahwa siswa 1 memenuhi indikator kedua walaupun ada belum tepat sedangkan siswa 2 belum memenuhi indikator kedua secara tepat yaitu (2) menyelesaiakan masalah yang melibatkan ekpresi matematis.

Pada pertemuan kelima untuk indikator kedua yaitu kemampuan menyelesaikan masalah yang melibatkan ekspresi matematis, Siswa 1 mampu menyelesaikan permasalah no b dan c dengan tepat dan perhitungan serta langkah-langkah penyelesaian juga benar sesuai perintah soal. Siswa 2 tidak menulis diketahui dan ditanya, namun langsung mencari keliling dengan menggunakan rumus keliling belah ketupat yaitu $\mathrm{k}=10+8+6=24$. Rumus yang digunakan salah yang benar yaitu $4 \mathrm{x}$ sisi dan hasilnya juga salah. Siswa 2 belum mampu menyelesaikan permasalah no b dengan tepat dan perhitungan serta langkah-langkah penyelesaian juga salah. Berikut Hasil jawaban siswa 2 untuk soal no b.

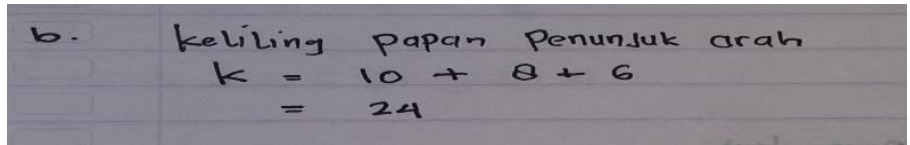

Gambar 11. Hasil Jawaban siswa 2 no b

Siswa 2 mengantikan nilainya ke dalam rumus luas belah ketupat yaitu $1 / 2 \times \mathrm{d} 1 \times \mathrm{x} 2=1 / 2 \mathrm{x} d 1$ x d $2=1 / 2 \times 10 \times 8 \mathrm{~cm}=40$. Jadi, luas papan petunjuk arah adalah 40. Namun, hasil luas papan penunjuk arah salah, karena untuk diagonal pertama dan kedua salah yang benar yaitu $\mathrm{d} 1=2 \times 8 \mathrm{~cm}=$ $16 \mathrm{~cm}, \mathrm{~d} 2=2 \times 6 \mathrm{~cm}=12 \mathrm{~cm}$. Siswa 2 mampu menyelesaikan permasalah no c dengan tepat dan perhitungan serta langkah-langkah penyelesaian juga benar, namun untuk nilai diagonal pertama dan diagonal kedua salah. Berikut Hasil jawaban siswa 2 untuk soal no c.

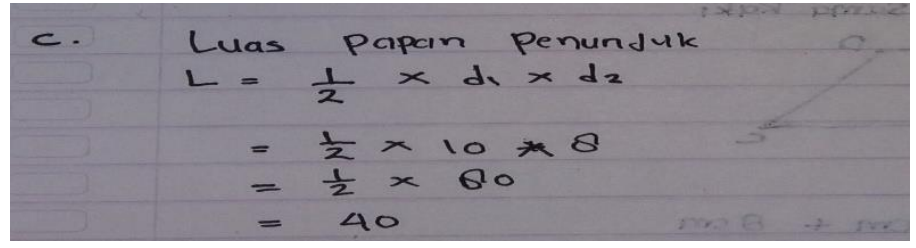

Gambar 12. Hasil Jawaban Siswa 2 no c.

Berdasarkan hasil jawaban siswa pada pertemuan kelima dapat disimpulkan bahwa siswa 1 memenuhi indikator kedua walaupun ada belum tepat sedangkan siswa 2 belum memenuhi indikator kedua secara tepat yaitu (2) menyelesaiakan masalah yang melibatkan ekpresi matematis.

Pada pertemuan keenam untuk indikator kedua yaitu kemampuan menyelesaikan masalah yang melibatkan ekspresi matematis, Siswa 1 mampu menyelesaikan permasalah no b dan c dengan tepat dan perhitungan serta langkah-langkah penyelesaian juga benar sesuai perintah soal. Siswa 2 tidak menulis diketahui dan ditanya, namun langsung mengerjakannya yaitu menggunakan rumus keliling layang-layang $=2 \times(90 \mathrm{~cm}+1 \mathrm{~m})=2 \times 91=182$. Siswa 2 belum mampu mampu menyelesaikan permasalah no $\mathrm{b}$ dengan tepat dan perhitungan serta langkah-langkah penyelesaian salah yaitu hasilnya nilai yang digantikan ke dalam keliling salah yang benar yaitu $85 \mathrm{~cm}+105 \mathrm{~cm}$. Berikut Hasil jawaban siswa 2 untuk soal no b.

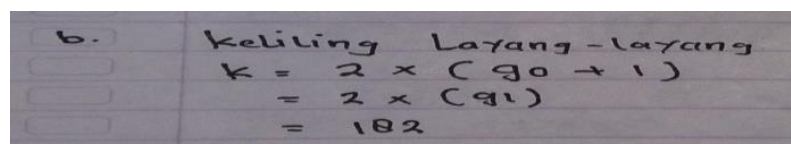

Gambar 13. Hasil Jawaban siswa 2 no b 
Siswa IR tidak menulis diketahui dan ditanya, namun lansung mengerjakannya ke rumus luas layang-layang yaitu $\mathrm{L}=1 / 2 \times \mathrm{d} 1 \times \mathrm{d} 2=1 / 2 \times 90 \times 1=1 / 2 \times 90=45$. Siswa IR belum mampu menyelesaikan permasalah no $\mathrm{c}$ dengan tepat dan perhitungan serta langkah-langkah penyelesaian juga benar namun hasilnya salah karena tidak mengubah diagonal kedua dari $1 \mathrm{~m} \mathrm{ke} \mathrm{cm}$. Berikut Hasil jawaban siswa 2 untuk soal no c.

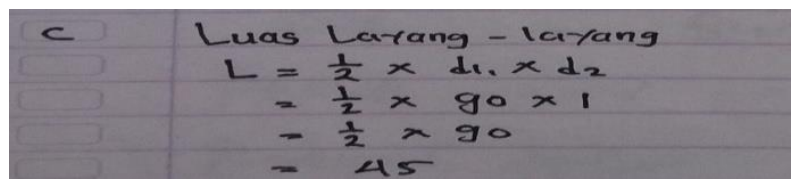

Gambar 14. Hasil Jawaban Siswa 2 no c

Berdasarkan hasil jawaban siswa pada pertemuan keenam dapat disimpulkan bahwa siswa 1 memenuhi indikator kedua walaupun ada belum tepat sedangkan siswa 2 belum memenuhi indikator kedua secara tepat yaitu (2) menyelesaiakan masalah yang melibatkan ekpresi matematis.

Berdasarkan penjelasan diatas, dapat disimpulkan bahwa pada pertemuan I sampai 6 untuk indikator ketiga yaitu (2) menyelesaikan masalah yang melibatkan ekspresi matematis sebagian besar siswa memenuhi indikator dan mengalami perkembangan.

\section{Kemampuan Menuliskan Langkah-Langkah Penyelesaian Masalah Matematika}

Berdasarkan hasil jawaban siswa diatas dapat disimpulkan bahwa pada pertemuan satu samapi ke enam untuk indikator ketiga yaitu (3) menuliskan langkah-langkah penyelesaian masalah matematika sebagian besar siswa memenuhi indikator dan mengalami perkembangan.

Berdasarkan penjelasan dari pertemuan I sampai pertemuan VI dapat dilihat bahwa kemampuan representasi matematis siswa dengan kriteria sedang (siswa 1) mengalami perkembangan di setiap pertemuan, namun ada beberapa langkah penyelesaian yang salah. Sedangkan siswa dengan kriteria rendah (siswa 2) pada pertemuan pertama sampai keenam masih belum mencapai indikator, tetapi pada pertemuan kedua mengalami perkembangan untuk indikator pertama sudah tercapai sedangkan untuk indikator kedua dan ketiga belum tercapai dengan baik, namun mengalami perkembangan.

Berdasarkan uraian di atas dapat disimpulkan bahwa kemampuan reprseantasi matematis siswa mengalami perkembangan. Meskipun tidak semua siswa mengalami perkembangan dengan baik, namun secara keseluruhan kemampuan representasi matematis siswa dapat dikatakan berkembang.

Berdasarkan hasil penelitian terlihat pembelajaran dengan model PBL dapat membantu menumbuhkan perkembangan kemampuan representasi matematis siswa. Meskipun siswa belum dapat memenuhi semua indikator yang diukur, namun terlihat sebahagian besar siswa telah dapat memenuhi sebahagian besar indikator representasi matematis yaitu (1) menyajikan data atau informasi dari suatu masalah ke representasi gambar, diagram, grafik atau tabel, (2) menyelesaikan masalah yang melibatkan ekspresi matematis. Hanya satu indikator kemampuan representasi matematis yang tidak terpenuhi yaitu menuliskan langkah-langkah penyelesaian masalah matematika . Demikian pula temuan Merritt, Lee, Rillero, Kinach (2017) bahwa pembelajaran dengan model PBL baik untuk menumbuhkan kemampuan belajar siswa serta membantu meningkatkan pengetahuan dalam proses pembelajaran. Allen, Duch, dan Groh (2001) menyatakan bahwa penyelesaian masalah non rutin 
dalam pembelajaran dengan model PBL dapat memotivasi siswa mengindentifikasi, meneliti konsep dan prinsip-prinsip serta mengetahui solusi yang tepat untuk menyelesaikan masalah yang diberikan.

Hasil penelitian ini sesuai dengan penelitian yang dilakukan oleh Pujiastuti (2008) yang menemukan bahwa sebagian besar siswa masih lemah dalam merepresentasikan ide melalui lisan atau teks tertulis. Selain itu, penelitian Mahardiyanti (2014) mengemukakan bahwa pembelajaran dengan menggunakan model PBL dapat meningkatkan kemampuan representasi dan hasil belajar siswa. Hal ini sesuai juga dengan temuan penelitian oleh Tsani (2015) bahwa pembelajaran menggunakan model PBL dapat meningkatkan kemampuan-kemampuan matematis yaitu kemampuan representasi dan komunikasi matematis. Hal ini disebabkan siswa dituntut secara individu maupun kelompok untuk mengemukakan solusi-solusi masalah yang diberikan melalui representasi yang mungkin dengan PBL. Siswa perlu diberikan waktu yang cukup untuk membiasakannya menggunakan kemampuan representasi matematis melalui pemecahan berbagai masalah.

\section{Self Confindence Siswa}

Self Confindence siswa diukur dengan menggunakan angket yang dibagikan kepada siswa di akhir pembelajaran yang terdiri dari 20 butir pernyataan yang harus diisi oleh siswa setelah belajar menggunakan model pembelajaran PBL. Berikut tabel hasil analisis angket untuk Self Confindence dari masing-masing siswa.

\begin{tabular}{|c|c|c|c|c|c|}
\hline Indikator & Pernyataan & SS & $\mathbf{S}$ & TS & STS \\
\hline \multirow{3}{*}{$\begin{array}{ll}\text { Percaya diri dalam } \\
\text { menghadapi kegagalan dan } \\
\text { keberhasilan }\end{array}$} & 1 & 20 & 7 & - & - \\
\hline & 2 & 6 & 14 & 7 & - \\
\hline & 3 & 2 & 2 & 5 & 18 \\
\hline \multicolumn{2}{|l|}{ Rata-Rata } & $34.6 \%$ & $28.4 \%$ & $14.8 \%$ & $22.2 \%$ \\
\hline $\begin{array}{l}\text { Percaya diri dalam bersaing } \\
\text { dan dibandingkan dengan } \\
\text { teman-temannya }\end{array}$ & 4 & 5 & 9 & 11 & 2 \\
\hline \multicolumn{2}{|l|}{ Rata-rata } & $18.5 \%$ & $33.3 \%$ & $40.7 \%$ & $7.4 \%$ \\
\hline \multirow[b]{2}{*}{$\begin{array}{l}\text { Tahu keterbatasan diri dalam } \\
\text { menghadapi persaingan } \\
\text { dengan teman-temannya }\end{array}$} & 5 & 18 & 9 & - & - \\
\hline & 6 & 3 & 8 & 14 & 2 \\
\hline \multicolumn{2}{|l|}{ Rata-rata } & $38.9 \%$ & $31.5 \%$ & $25.9 \%$ & $3.7 \%$ \\
\hline \multirow{4}{*}{$\begin{array}{l}\text { Tahu keterbatasan diri dalam } \\
\text { menghadapi matematika }\end{array}$} & 7 & 4 & 5 & 16 & 2 \\
\hline & 8 & 17 & 10 & - & - \\
\hline & 9 & 19 & 7 & - & 1 \\
\hline & 10 & 6 & 4 & 7 & 10 \\
\hline \multicolumn{2}{|l|}{ Rata-rata } & $42.6 \%$ & $24.1 \%$ & $21.3 \%$ & $\begin{array}{l}12.03 \\
\%\end{array}$ \\
\hline \multirow{4}{*}{$\begin{array}{l}\text { Percaya bahwa matematika } \\
\text { adalah sesuatu yang abstrak }\end{array}$} & 11 & 2 & 15 & 6 & 4 \\
\hline & 12 & 6 & 17 & 4 & - \\
\hline & 13 & 8 & 17 & 1 & 1 \\
\hline & 14 & 5 & 1 & 19 & 2 \\
\hline \multicolumn{2}{|l|}{ Rata-rata } & $21.3 \%$ & $46.3 \%$ & $27.8 \%$ & $6.5 \%$ \\
\hline \multirow[b]{2}{*}{$\begin{array}{l}\text { Percaya bahwa matematika } \\
\text { adalah sesuatu yang sangat } \\
\text { berguna }\end{array}$} & 15 & 19 & 8 & - & - \\
\hline & 16 & 10 & 9 & 5 & 3 \\
\hline \multicolumn{2}{|l|}{ Rata-rata } & $53.7 \%$ & $31.5 \%$ & $9.3 \%$ & $5.6 \%$ \\
\hline
\end{tabular}




\begin{tabular}{|l|c|c|c|c|c|}
\hline $\begin{array}{l}\text { Percaya bahwa matematika } \\
\text { sebagai suatu seni, anlitis dan } \\
\text { rasional }\end{array}$ & 17 & 1 & 14 & 10 & 2 \\
\hline Rata-rata & & $3.7 \%$ & $51.9 \%$ & $\begin{array}{l}37.03 \\
\%\end{array}$ & $7.4 \%$ \\
\hline $\begin{array}{l}\text { Percaya bahwa matematika } \\
\text { adalah suatu kemampuan } \\
\text { bawaan }\end{array}$ & 18 & 8 & 7 & 12 & 1 \\
\cline { 2 - 7 } & 20 & 19 & 8 & - & - \\
\hline Rata-rata & $41.97 \%$ & $38.3 \%$ & $\begin{array}{l}16.04 \\
\%\end{array}$ & $4.93 \%$ \\
\hline
\end{tabular}

Berdasarkan data diatas, untuk indikator Self Confidence yaitu (1) penilaian siswa mengenai percaya diri dalam menghadapi kegagalan dan keberhasilan saat mengerjakan soal matematika artinya siswa percaya diri dalam menghadapi kegagalan maupun keberhasilan saat mengerjakan soal matematika. (2)Indikator penilaian siswa mengenai percaya diri dalam bersaing dan dibandingkan dengan teman-temannya saat mengerjakan soal matematika artinya siswa hanya sedikit yang percaya diri dalam bersaing dengan teman-temannya. (3)Indikator penilaian siswa mengenai tahu keterbatasan diri dalam menghadapi persaingan dengan teman-temannya saat mengerjakan soal matematika artinya siswa lebih tahu kemampuannya untuk bersaing dengan teman-temannya. (4)Indikator penilaian siswa mengenai tahu keterbatasan diri dalam menghadapi matematika saat mengerjakan soal matematika artinya siswa lebih tahu sejauh mana kemampuannya dalam mengerjakan soal matematika.(5)Indikator penilaian siswa percaya bahwa matematika adalah sesuatu yang abstrak, artinya banyak siswa yang menganggap bahwa matematika itu abstrak. (6)Indikator penilaian siswa Percaya bahwa matematika adalah sesuatu yang sangat berguna artinya banyak siswa menganggap bahwa matematika itu berguna.(7)Indikator penilaian siswa percaya bahwa matematika sebagai suatu seni, anlitis dan rasional artinya hanya sedikit siswa yang menganggap bahwa matematika itu sebagai suatu seni, analitis dan rasional. (8)Indikator penilaian siswa percaya bahwa matematika adalah suatu kemampuan bawaan artinya banyak siswa yang menganggap bahwa kemampuan matematika itu adalah kemampuan bawaan.

Berdasarkan hasil dari angket siswa dan soal tes Kemampuan Representasi Matematis yaitu jika siswa tidak memiliki self confidence dalam menyelesaikan soal matematika maka siswa itu tidak akan berani mengungkapkan pendapat dan jawaban soal kurang tepat. Menurut Hendriana (2012) kepercayaan diri akan memperkuat motivasi mencapai keberhasilan, karena semakin tinggi kepercayaan terhadap kemampuan diri sendiri, semakin kuat pula semangat untuk menyelesaikan pekerjaannya. Hal ini di dukung oleh beberapa penelitian terdahulu yang mengungkapkan bahwa terdapat assosiasi positif antara self confidence dalam belajar matematika dengan hasil belajar matematika (Hannula, etal.,2004). Menurut Suhendri, (2012) mengatakan bahwa hasil belajar matematika tinggi untuk setiap siswa yang memiliki indeks self confidence yang tinggi pula. Self confidence dapat tumbuh pada diri setiap orang. Self confidence dapat mendorong seseorang dalam mewujudkan harapan serta cita-cita, karena jika individu tidak mempunyai self confidence maka dia akan ragu-ragu dalam mengambil keputusan yang akan merugikan individu serta orang lain. kemampuan Self confidence siswa dalam penelitian ini memiliki dampak positif terhadap kemampuan representasi matematis siswa terhadap proses pembelajaran PBL sesuai dengan indikator Self Confindece. 


\section{KESIMPULAN}

Hasil penelitia ini terlihat bahwa kemampuan representasi matematis siswa dengan kriteria sedang (siswa 1) dan kriteria rendah (siswa 2) pada pertemuan pertama sampai pertemuan keenam mengalami perkembangan. Salah satu siswa mengalami perkembangan dengan baik, namun secara keseluruhan kemampuan representasi matematis siswa tersebut dapat dikatakan berkembang. Hal ini terlihat dari setiap pertemuan, siswa sudah mampu memenuhi sebagian besar indikator kemampuan representasi matematis. Penelitian ini juga menunjukkan perlu waktu yang cukup untuk membiasakan siswa melatih kemampuan representasi matematis. kemampuan Self Confidence siswa dalam penelitian ini memiliki dampak positif terhadap kemampuan representasi matematis siswa terhadap proses pembelajaran berlangsung sesuai dengan indikator Self Confidence.

\section{REFERENCES}

Alhadad, S. F. (2010). Meningkatkan Kemampuan Representasi Multipel Matematis, Pemecahan Masalah Matematis dan Self Esteem SiswaSMP melalui Pembelajaran dengan Pendekatan Open Ended. Bandung: Disertasi UPI.

Amir, T (2009). Inovasi Pendidikan Melalui Problem Based Learning. Jakarta: Kencana Prenada Media Grup.

Chamberlin, S. A., \& Moon, S. M. (2008). How Does the Problem Based Learning Approach Compare to The Model-Eliciting Acvtivity in Mathematics. Tersedia di http://cimt. plymouth. ac. uk [diakses 16-01-2015].

English, Lyn D. (2014). Handbook of International Research In Mathematics Education. New York: Routledge.

Hendriana.H,dkk.(2017). Hard Skills dan Soft Skills Matematik Siswa. Bandung: PT Refika Aditama.

Hannula,M. S., Maijala, H., \& Pehkonen, E. (2004). Development Of understanding and selfconfidence in mathematics; Grades 5-8. Proceedings of the 28th Conference of the International Group for the Psychology of Mathematics Education, 3, 17-24.

Huri Suhendri. (2012). Pengaruh Kecerdasan Matematis-Logis, Rasa Percaya Diri, Dan Kemandirian Belajar Terhadap Hasil Belajar Matematika. Prosiding Seminar Nasional Matematika dan Pendidikan Matematika UNY 10 November 2012.

Ibrahim, M \& Nur, M. (2000). Pembelajaran Berbasis Masalah.Surabaya: UNESA University Press.

Merritt, J., Lee, M. Y., Rillero, P., \& Kinach, B. M. (2017). Problem-Based Learning in K-8 Mathematics and Science Education: A Literature Review. Interdisciplinary Journal of Problem-Based Learning, 11(2), 3.

Mahardiyanti, T. (2014). Penerapan Metode Pembelajaran Problem Based Learning (PBL) untukMeningkatkan Kemampuan Representasi Matematis Siswa Kelas V SDN Bader 01 tahun Pelajaran 2014/2015. Jurnal Ilmiah Pendidikan, 2(2),142-149.

Majid, A. (2014). Implementasi Kurikulum 2013. Bandung: Interes Media. 
Malan, S. B and Ndlovu, M. (2014). Introducing Problem-Based Learning (Pbl) Into a Foundation Programme to Develop Self-Directed Learning Skills. South African Journal of Education, Vol.34(1), Hal. 1-16.

Mahmudi, 2010, Manajemen Kinerja Sektor Publik. Yogyakarta : UPP STIM YKPN.

Merritt, J., Lee, M. Y., Rillero, P., \& Kinach, B. M. (2017). Problem-Based Learning in K-8 Mathematics and Science Education: A Literature Review. Interdisciplinary Journal of Problem-Based Learning, 11(2), 3.

Mullis, I. V., Martin, M. O., Foy, P., \& Arora, A. (2012). TIMSS 2011 international results in mathematics. International Association for the Evaluation of Educational Achievement. Herengracht 487, Amsterdam, 1017 BT, The Netherlands.

Mudzakir, H. S. (2006). Strategi Pembelajaran Think-Talk-Write untuk Meningkatkan Kemampuan Representasi Matematik Beragam Siswa SMP. Disertasi UPI.

Panaoura, A. (2012). Young Students'self-Beliefs About Using Representations In Relation To The Geometry Understanding. International Journal for Mathematics Teaching \& Learning.

Pujiastuti, H. (2008). Pembelajaran kontekstual untuk meningkatkan kemampuan koneksi dan representasi siswa SMP. Tesis SPS UPI Bandung.

Rahmawati. (2016). Seminar hasil TIMSS 2015. Puspendik Kemendikbut.1-10

Rohayati, I. (2011). Program Bimbingan Teman Sebaya Untuk Meningkatkan Percaya Diri Siswa. Jurnal UPI, Edisi Khusus, (1).

Sugiyono. (2014). Metodelogi Penelitian Pendidikan pendekatan Kuantitatif,kualitatif dan $R \& D$. Bandung : Alfabeta.

Tsani, A. M. (2015). Penerapan Model Pembelajaran Berbasis Masalah Untuk Meningkatkan Kemampuan Komunikasi dan Representasi Matematis Siswa. Seminar Nasional Matematika dan Pendidikan Matematika UNY, 99-104.

Widarti, S., Yunarti, T., \& Asnawati, R. (2014). Penerapan Model PBL untuk Meningkatkan Kemampuan Representasi Matematis Siswa. Jurnal Pendidikan Matematika Unila, 2(4). 